\title{
Origins of persistent macroeconomic imbalances in the Euro area
}

Citation for published version (APA):

Holinski, N., Kool, C. J. M., \& Muysken, J. (2010). Origins of persistent macroeconomic imbalances in the Euro area. METEOR, Maastricht University School of Business and Economics. METEOR Research Memorandum No. 026 https://doi.org/10.26481/umamet.2010026

Document status and date:

Published: 01/01/2010

DOI:

10.26481/umamet.2010026

Document Version:

Publisher's PDF, also known as Version of record

\section{Please check the document version of this publication:}

- A submitted manuscript is the version of the article upon submission and before peer-review. There can be important differences between the submitted version and the official published version of record.

People interested in the research are advised to contact the author for the final version of the publication, or visit the DOI to the publisher's website.

- The final author version and the galley proof are versions of the publication after peer review.

- The final published version features the final layout of the paper including the volume, issue and page numbers.

Link to publication

\footnotetext{
General rights rights.

- You may freely distribute the URL identifying the publication in the public portal. please follow below link for the End User Agreement:

www.umlib.nl/taverne-license

Take down policy

If you believe that this document breaches copyright please contact us at:

repository@maastrichtuniversity.nl

providing details and we will investigate your claim.
}

Copyright and moral rights for the publications made accessible in the public portal are retained by the authors and/or other copyright owners and it is a condition of accessing publications that users recognise and abide by the legal requirements associated with these

- Users may download and print one copy of any publication from the public portal for the purpose of private study or research.

- You may not further distribute the material or use it for any profit-making activity or commercial gain

If the publication is distributed under the terms of Article $25 \mathrm{fa}$ of the Dutch Copyright Act, indicated by the "Taverne" license above, 


\section{Maastricht University}

Nils Holinski, Clemens Kool, Joan Muysken

Origins of persistent macroeconomic imbalances in the Euro area

$\mathrm{RM} / 10 / 026$

\section{METEOR}

Maastricht University School of Business and Economics

Maastricht Research School of Economics

of Technology and Organization

\section{P.O. Box 616}

NL - 6200 MD Maastricht

The Netherlands 


\title{
Origins of persistent macroeconomic imbalances in the Euro area*
}

\author{
Nils Holinski ${ }^{a, \dagger}$, Clemens Kool $^{b}$, Joan Muysken ${ }^{a}$ \\ ${ }^{a}$ Department of Economics, Maastricht University, PO BOX 616, 6200 MD Maastricht, The Netherlands \\ ${ }^{b}$ Utrecht School of Economics, Janskerkhof 12, 3512 BL Utrecht, The Netherlands
}

May 7, 2010

\begin{abstract}
In this paper we document the growing dispersion of external and internal balances between countries in the North and South of the Euro area over the time period 1992 to 2007. We find a persistent divergence process that seems to have started with the introduction of the common currency and has its roots in the savings and investment behavior of private sectors. We dismiss the common argument in the literature that imbalances are the temporary outcome of an overall European economic convergence process and argue that future research should place greater emphasis on country heterogeneity in behavior to fully understand economic developments in the Euro area and to derive policy implications.
\end{abstract}

JEL Classification: F15, F32, F41

Keywords: Euro area, current acccount imbalances, Stability and Growth Pact

${ }^{*}$ The authors would like to thank participants of the European Monetary Forum Conference 2010 in Bern, the NAKE Research Day 2010 in Utrecht and the macro group seminar at Maastricht University.

${ }^{\dagger}$ Corresponding author: Department of Economics, Maastricht University, PO Box 616, MD 6200 Maastricht, The Netherlands. Tel:+31 433883653, Fax: +31 43 3884864, E-MAIL: N.Holinski@maAstrichtuniversity.NL 


\section{Introduction}

The broad fiscal consolidation among member countries of the European Economic and Monetary Union (EMU) since the adoption of the Euro in 1999 changed dramatically with the unfolding of the current financial and economic crisis in 2008. Not only are all member countries now in breach with the self-imposed budgetary constraints of the Treaty of Maastricht, some are even on the verge of a sovereign debt crisis. International capital markets reacted by demanding risk premiums for continuing holding public debt of Spain, Portugal and Ireland. Greece even faces such unsustainable terms on international capital markets that it effectively can no longer access these markets and the group of Euro area countries together with the International Monetary Fund had to step in as lenders of last resort in May $2010 .{ }^{1}$

The situation of Greece has also turned the spot light on the alarming indebtedness of some Euro Area countries, in particular Portugal, Spain and Ireland. Without doubt, the debt levels of these countries and the corresponding responses of international investors must be evaluated in light of the current economic environment. However, in order to understand the situation in a comprehensive way and to define appropriate policy responses one should look beyond the current economic crisis and the focus on government debt. We argue in this paper that there has been a structural economic divergence process among Euro area countries that seems to have started already with the introduction of the common currency in 1999 and cannot be confined to the public sector only. We elaborate both points below.

To facilitate our analysis, we distinguish between two clusters of Euro area countries, ${ }^{2}$ North consisting of Austria, Finland, Germany and the Netherlands and South consisting of Greece, Ireland, Portugal and Spain, and two sub-periods 1992 to 1998 and 1999 to 2007. The first sub-period spans the run-up to EMU between the signing of the Treaty of Maastricht and the introduction of the Euro, while the second can be characterized as a time period of moderate and stable economic expansion between the introduction of the Euro and the recent economic crisis. Providing first a comprehensive and consistent review of savings and investment behaviour and current account imbalances, we show that Northern countries can be characterized as prudent net savers, consuming moderately and providing for their future. This holds for their public and private sectors alike and is reflected in stable and high private saving rates, balanced government

\footnotetext{
${ }^{1}$ Greece, with a budget deficit of 13.6 percent of GDP and an expected government debt burden of about 150 percent of GDP over the medium-term, faced in April 2010 a yield spread of up to 10 percentage points over comparable German debt instruments.

${ }^{2}$ We elaborate this clustering below. Our analysis would not change fundamentally when we include Belgium, Luxembourg and France under North and Italy under South.
} 
savings and persistent current account surpluses. The net foreign asset positions of these countries are almost balanced on average. On the other hand we observe that the private and public sector of Southern countries continuously consume in excess of their resources and consequently these countries show negative balances on all three accounts. Moreover the servicing of high net foreign debt positions constitutes a considerable burden for these countries. Thus we observe growing external and internal imbalances across the Euro area and an increasing indebtedness of the South to the North.

We next evaluate the disparate situation between Northern and Southern Europe in the light of the literature. The standard argument is that imbalances can be attributed to intertemporal maximization and thus to underlying fundamentals of a European convergence process (Blanchard and Giavazzi (2002), Ahearne et al. (2007) and Arghyrou and Chortareas (2008)). Countries with lower per-capita income and lower productivity attract foreign capital investment. In the same adjustment process, relative inflation is likely to rise, leading to real exchange rate appreciation and a loss of international competitiveness. As a result, current account deficits arise that match the surpluses on the capital accounts. These adjustments are all the more credible in the presence of integrated real and financial markets. Thus cross-country imbalances may well be perceived as a success of and not a threat to the Euro.

We beg to differ on three grounds. First, the Euro area divergence of consumption and spending behavior is unprecedented and implies an unsustainable transfer of wealth from the North to the South. A complication is that most of the divergence occurs in the private sector where economic policy coordination is largely lacking. The Treaty of Maastricht is not competent in this respect. Second, the Euro area countries form a common currency area that abolished nominal interest and exchange rate mechanisms and seeks to achieve low and common inflation rates. Third, we show that data do not provide evidence for a strong convergence process.

Our empirical analysis advocates that future research into causes for the observed dispersion in current account balances should look for alternatives to the economic convergence hypothesis. We believe that country heterogeneity in particular cross-country differences in spending habits, planning horizons and levels of risk aversion are a promising research avenue. Placing behavioral considerations on par with economic fundamentals also provides a suitable framework for deriving policy implications. One such policy recommendations is to revise the Stability and Growth Pact to place greater weight on external imbalances.

The rest of the paper is organized as follows. Section 2 provides a systematic review of internal and external imbalances in the Euro area by distinguishing the private and public sector 
and their respective savings and investment behavior. In addition we disaggregate Euro area current accounts into trade balances, net factor income and net current transfers. In Section 3 we review the corresponding literature and analyze the common argument that Euro area imbalances are part of an overall convergence process. Section 4 concludes with a brief outline of the broader perspective and policy implications.

\section{Savings behavior and current account imbalances}

Figure 1: Current account (\% of GDP), 1992-2007

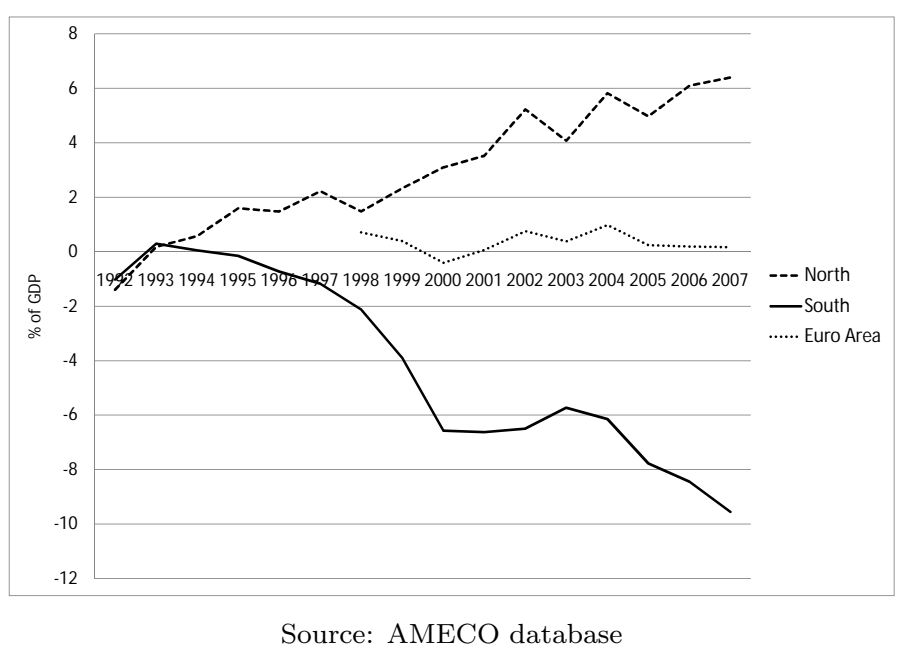

In our empirical analysis we largely employ data taken from the AMECO database of the European Commission which allows for a detailed and consistent breakdown of all relevant variables. The country groups are obtained using the k-means clustering methodology based on data for current accounts and private saving rates, both in levels and first differences. The two country groups that are always clustered together independent of the choice of variable or taking levels or differences are Austria, Finland, Germany and the Netherlands, which we call North, and Greece, Ireland, Portugal and Spain, called South. ${ }^{3}$ Belgium, France, Italy and Luxembourg are clustered differently depending on whether data are employed in levels or first differences, but this is independent of the choice of variable. They are grouped to North based on data in levels and belong to South if the cluster analysis is conducted with data in first differences. In our analysis, we will concentrate on the polar clusters and leave Belgium, France, Italy and Luxembourg aside. However, our conclusions remain roughly the same when

\footnotetext{
${ }^{3}$ Gros (2010) discusses current differences between those countries that we cluster as South. Our analysis focuses on a longer time period during which they form a more homogeneous set of countries.
} 
we include Belgium, France and Luxembourg under North and Italy under South.

From an economic accounting perspective current account imbalances occur if the demand of a country by households, firms and the government falls short of its output or vice versa. Thus as a general rule current account imbalances should not give rise to concerns as long as they are temporary in nature, e.g. in the event of adverse shocks countries are able to retain stable consumption paths. The situation in the Euro area is different however with current account imbalances that are growing persistently.

Table 1: Disaggregation of average current accounts in the Euro area

\begin{tabular}{|c|c|c|c|c|c|c|}
\hline \multirow[b]{3}{*}{ South } & \multicolumn{2}{|c|}{ Current Account } & \multicolumn{2}{|c|}{$\begin{array}{c}\text { Public } \\
\text { Net Savings }\end{array}$} & \multicolumn{2}{|c|}{$\begin{array}{c}\text { Private } \\
\text { Net Savings }\end{array}$} \\
\hline & $1992-1998$ & $1999-2007$ & $1992-1998$ & 1999-2007 & $1992-1998$ & 1999-2007 \\
\hline & -0.7 & -6.8 & -5.7 & -2.1 & 5.0 & -4.7 \\
\hline North & 0.9 & 4.6 & -3.3 & -0.2 & 4.2 & 4.8 \\
\hline
\end{tabular}

Source: AMECO database

Figure 1 provides evidence for persistently rising current account imbalances between the two country groups of the Euro area that we have defined above. Since the inception of the EMU process the average current account balance of Northern countries has been continuously growing from a small deficit in 1992 to more than 6 percent of GDP in 2007, while at the same time current accounts of Southern countries deteriorated from close to zero in the early 1990s to a tremendous deficit of almost 10 percent of GDP in $2007 .{ }^{4}$ In comparison, the current account deficits of the US in the ongoing discussion of global imbalances peaked at a level of about 6 percent of GDP.

Most of the current account divergence can be attributed to the second subperiod and hence corresponds to the introduction of the Euro as a common currency. The first column of Table 1 confirms that in the run-up to EMU, 1992-1998, current account differences were relatively minor with an average deficit for Southern countries of 0.7 percent of GDP compared to an average surplus for Northern countries of 0.9 percent of GDP. Since the introduction of the Euro, current accounts drifted apart by more than 11 percent of GDP and distinct groups of creditor and debtor countries emerged. Finally it is interesting to observe from Figure 1

\footnotetext{
${ }^{4}$ Note that throughout the paper we employ unweighted averages for the two country clusters to avoid that Germany dominates the Northern countries group and Spain the Southern countries group, respectively. The conclusions do hardly change when we use GDP weighted figures. The corresponding figures are available from the authors upon request.
} 
that despite underlying dispersions, the aggregate current account of the Euro area (EU-16) is hovering around zero at all times. This suggests the interpretation that Northern countries are essentially financing the current account deficits of Southern countries with their surpluses - either directly through capital flows from North to South or indirectly with non-Euro area countries acting as intermediaries.

To further explore the current account balances in the Euro area we proceed along two lines. First we view the contributions of saving $(S)$ and investment $(I)$ decisions of households and firms as the private sector and the government as the public sector to the evolution of current account balances

$$
C A=\underbrace{S-I}_{\text {public net savings }}+\underbrace{S-I}_{\text {private net savings }}
$$

and second, we consider the different components of the current account balance from an accounting perspective

$$
C A=T B+N F I+N C T
$$

with trade balance $(T B)$, net factor income $(N F I)$ and net current transfers $(N C T)$. Both approaches are revealing.

\subsection{Public versus private net saving rates}

We distinguish between the public sector consisting of the government and the private sector consisting of households and firms. Both contribute through saving and investment decisions to the evolution of a country's current account. Figures 2 and 3 show net savings of Northern and Southern countries as they emerge from their public and private sectors, respectively. In addition, columns 2 and 3 of Table 1 present the time averages for the two subperiods that we consider. A number of interesting facts are notable. Considering the contributions of the public sectors to the current account balances we find that notwithstanding a common upward trend for both country groups, Southern countries are persistently lagging behind by about 2 percent of GDP. In particular during the run-up to EMU, all governments managed to improve their initial deficit positions: Southern countries on average by 3.6 percent of GDP and Northern countries on average by 3.1 percent of GDP, respectively. Thereafter, since the introduction of the Euro, the public net savings of both country groups are fairly stable with an average deficit of 0.2 percent of GDP for North and an average deficit of 2.1 percent of GDP for South. In 
Figure 2: Public net savings (\% of GDP), 1992-2007

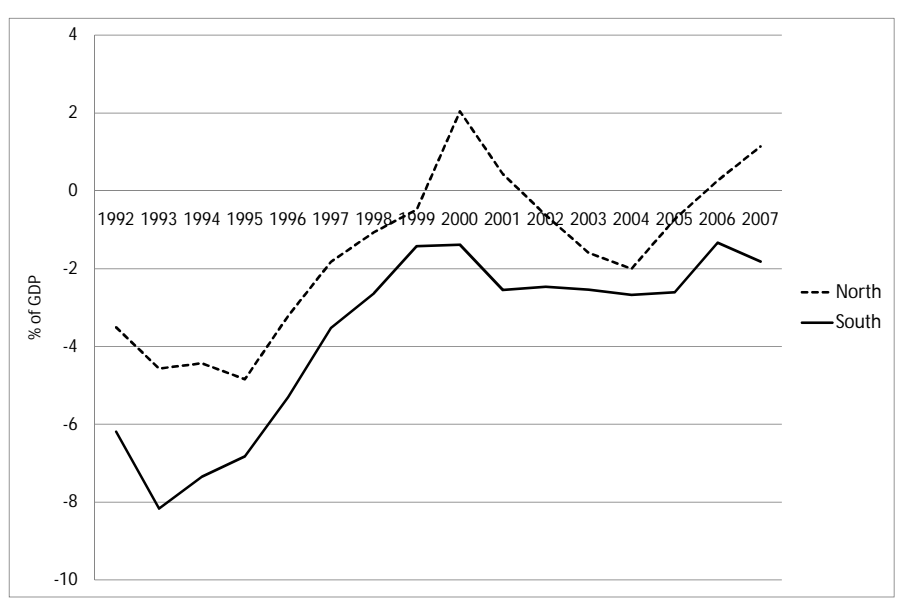

Figure 3: Private net savings (\% of GDP), 1992-2007

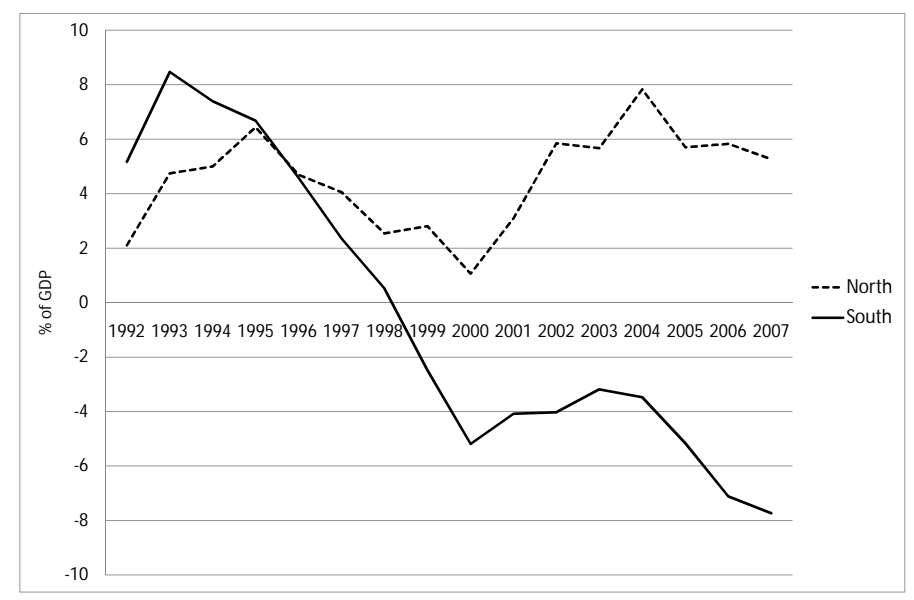

Source: AMECO database

summary, we can see from the data that public net savings seem to obey the criteria of the Treaty of Maastricht. However we note that the period of fiscal consolidation coincides with the upward phase of the business cycle and one could argue that, in particular South, should have done even more to weather the storm ahead.

To explain the current account divergence that we observe in Figure 1, we have to shift our attention to the private sectors, depicted in Figure 3. For Northern countries we find relatively steady private net savings that vary within a three-percent margin around 5 percent of GDP. No trend is detectable, neither in the run-up to EMU nor in the time period thereafter. For Southern countries however we observe a tremendous deterioration of private net savings exceeding 16 percent of GDP: from a surplus of 8 percent of GDP in the early 1990s to a deficit of the same magnitude in 2007. Also from column 3 of Table 1 we can see that private net 
Figure 4: Private savings (\% of GDP), 1992-2007

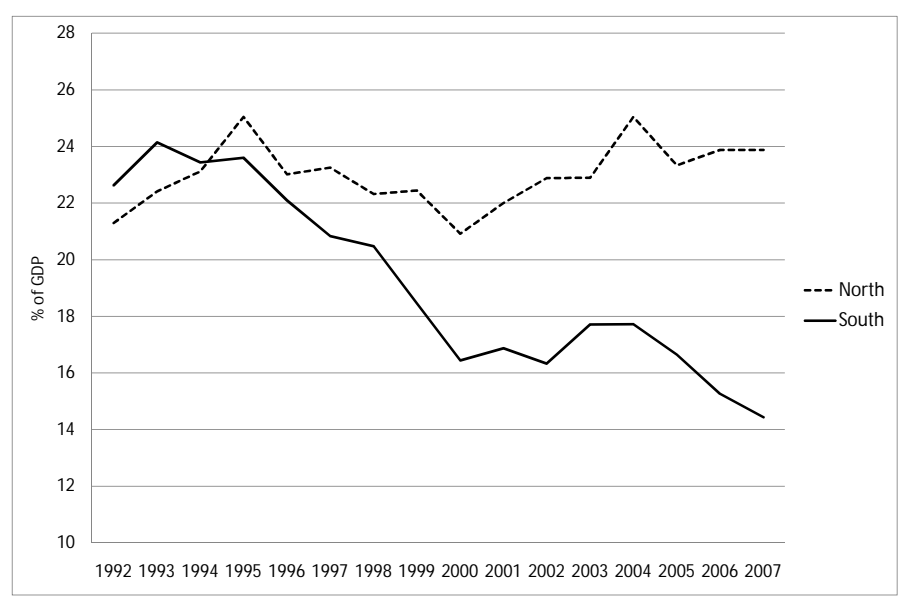

Figure 5: Private investment (\% of GDP), 1992-2007

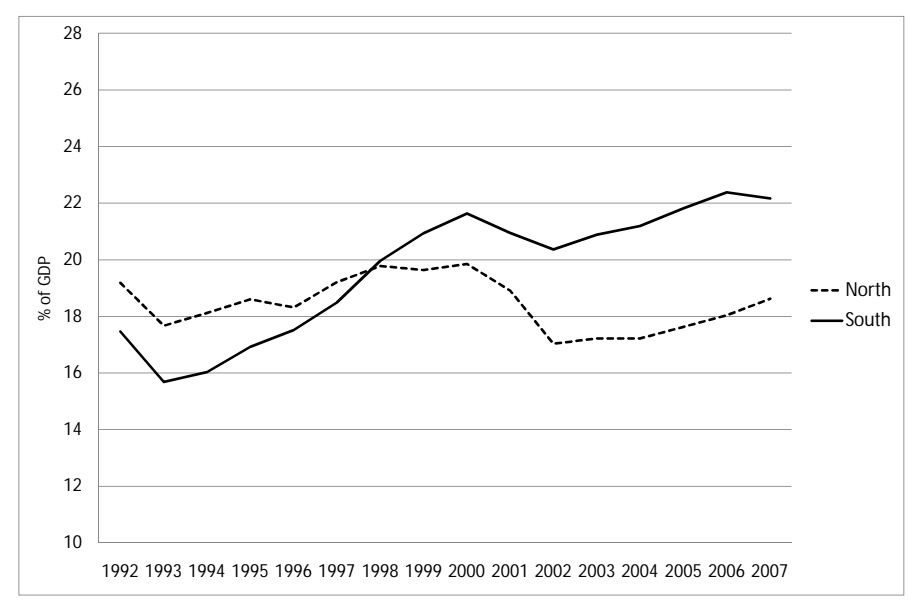

Source: AMECO database

savings of Southern countries were positive with 5 percent of GDP in the first subperiod, but turned negative with 4.7 percent of GDP in the second subperiod. Particularly interesting to observe is that in the South the net saving rates of the public and private sectors are almost one-to-one mirror images. That is during the run-up to EMU when we observed the most pronounced improvements of net savings in the public sector, we also observe the most distinct deteriorations of net savings in the private sector. For Southern countries, it seems as if the adjustment burden of the fiscal policy measures that are stipulated in the Treaty of Maastricht has a strong compensatory influence on the private sector. The joint conclusion of both figures is that the current account divergence in the Euro area can be explained by the interaction of the public and private sectors. While the public sectors in all countries reacted largely in the same way to the fiscal convergence criteria imposed on them, we find that the private sectors were 
Table 2: Disaggregation of average private net saving rates in the Euro area

\begin{tabular}{c|cccccc}
\hline \hline \multirow{2}{*}{} & \multicolumn{2}{|c}{$\begin{array}{c}\text { Private } \\
\text { Net Savings }\end{array}$} & \multicolumn{2}{c}{$\begin{array}{c}\text { Private } \\
\text { Savings }\end{array}$} & \multicolumn{2}{c}{$\begin{array}{c}\text { Private } \\
\text { Investment }\end{array}$} \\
\cline { 2 - 7 } South & $1992-1998$ & $1999-2007$ & $1992-1998$ & $1999-2007$ & $1992-1998$ & $1999-2007$ \\
\cline { 2 - 7 } North & 5.0 & -4.7 & 22.4 & 16.7 & 17.4 & 21.4 \\
\hline \hline
\end{tabular}

Source: AMECO database

differently prepared to cope with it. The private sectors of Northern countries could insulate themselves and showed no reaction to the current account improvements of their public sectors. In contrast, the private sectors of Southern countries more than set off the improvements of the public net savings with the result of an overall current account deterioration as shown in Figure 1.

To further shed light on what happened to private net savings in the Euro area, we proceed with their disaggregation into private savings and investments, in Figures 4 and 5, respectively. In addition we also present the corresponding time averages for the two subperiods in Table 2 . In line with private net savings, we find that private saving and investment rates of Northern countries remained largely unchanged over the past one and a half decades. While private savings fluctuate closely around 23 percent of GDP, private investment rates are 18.5 percent of GDP on average. This in itself is an interesting result: neither the preparation for, nor the introduction of a common currency (with all its far-reaching consequences) seem to have implications for the savings and investment behavior of households and firms in Northern countries. For Southern countries the situation is fundamentally different. From Figure 4 we can see that the tremendous deterioration of private net saving rates can be primarily attributed to the saving behavior of the private sector. The private saving rates per GDP dropped from a high of 24 percent in 1993 to almost 14 percent in 2007. This is also confirmed by Table 2. During the run-up to EMU both country groups displayed almost the same average private saving rates of about 22.5 percent of GDP, however with the introduction of the Euro it declined to an average of 16.7 percent of GDP in Southern countries, while remained by and large unchanged in Northern countries. Concomitant to falling private saving rates, we observe private investment growth in Southern countries that also contributed to the deterioration of their current accounts. The growth in private investment rates is largely confined to the time period of the run-up to EMU and might be triggered by the output growth prospects of the common currency area. From Table 2 we find that the average private investment rate for Southern countries is 17.4 percent of GDP prior 
to the introduction of the Euro and 21.4 percent of GDP thereafter.

Having established that private sectors are prime drivers of current account imbalances we proceed with taking an accounting perspective and disaggregate these imbalances into their components.

\subsection{Components of the current account}

Reviewing external and internal imbalances in the Euro area, we ultimately seek to answer the question of how sustainable these imbalances are, in particular for a common currency area that can no longer rely on nominal exchange rates and interest rates adjustments. In this respect, viewing the individual components of current accounts - trade balances, net factor income and net current transfers - is particularly informative as the mix of these components reveals how past external imbalances transmit into present and future years. In the absence of valuation gains, current account deficits in the past lead inevitably to the accumulation net foreign debt positions that need to be serviced out of current income. ${ }^{5}$ As such the situation of external imbalances in the Euro area will stretch into the future and accelerate the current divergences process.

Figure 6 shows the evolution of net foreign asset positions as a percentage of GDP over the time period 1992 to 2007. In accordance with the current account patterns in Figure 1 we find that Northern and Southern countries are holding similar net foreign debt positions of about 10 to 20 percent of GDP during the run-up to EMU. Since 2000 however differences in current account patterns begin to materialize in net foreign asset positions. Northern countries with average current account surpluses of 4.6 percent of GDP continuously reduced their foreign indebtedness to close to zero. For Southern countries mounting current account deficits took their toll. In 2007 they face a level of foreign indebtedness of close to 80 percent of GDP with concomitant consequences that are alarming. Figure 7 shows how the divergence of net foreign asset positions induces net foreign income payments that reinforce current trends. Following the deterioration of their net foreign asset positions, Southern countries have to pay an increasingly larger share of GDP to service their foreign creditors. In 2007 almost 6 percent of GDP has to be spent on net factor income payments. Northern countries on the other hand are net recipients of factor income in the range of 0.5 to 1 percent of GDP in the latest years. Figure 8 presents whether trade balances as differences of exports and imports of goods and services react to the

\footnotetext{
${ }^{5}$ For an empirical and theoretical discussion of valuation effects in the external adjustment process see, among others, Lane and Milesi-Ferretti (2005) and Holinski et al. (2009).
} 
Figure 6: Net foreign assets (\% of GDP), 1992-2007

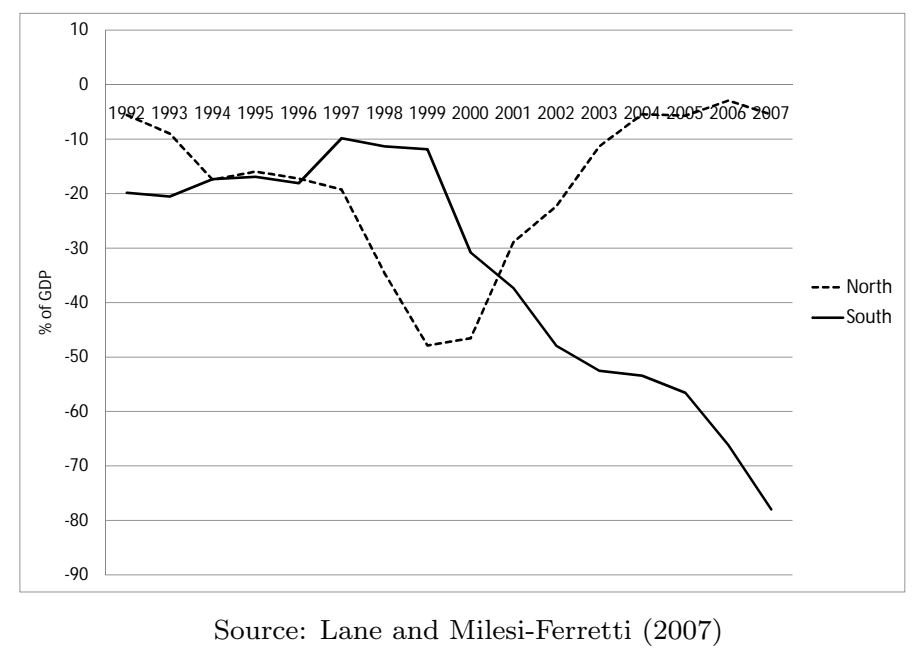

evolution of net factor income payments by restraining or expanding net imports.

Northern countries persistently improved their trade balances from about 1 percent of GDP in 1992 to more than 6 percent of GDP on 1992. There is no evidence that they adapted their behavior and consumed the extra income they earned on their net foreign asset positions lately. The same holds true for Southern countries, but with reversed signs. The trade balances of Southern countries decreased around the time of the introduction of the Euro from an average deficit of about 1 percent of GDP before to an average deficit of 2.5 percent of GDP thereafter. The relative stable trade balance deficits since 2000 are remarkable as they show no sign of restriction in net imports to compensate the tremendously increasing net factor income payments. This implies that the latter are directly passed on to the current account from where they feed back on the further accumulation of foreign debt. This process is unsustainable and will eventually lead to exploding foreign debt levels. To halt the accumulation of foreign debt, Southern countries will have to adopt their consumption behavior in a way as to offset the payments to foreign creditors.

The final component of the current account, net current transfers, is particularly prevalent in Europe as it captures, a.o., payments related to current international cooperation (AMECO, 2010). Figure 9 summarizes the evolution of net current transfers for both country groups over the time period 1992 to 2007. Three observations stand out. First, Northern countries are continuously transferring an average of 1 percent of GDP over the entire time period, while Southern countries are net recipients of current transfers for most of the time. Initially their net current transfers amount to more than 3 percent of GDP, but are steadily decreased to marginally 
Figure 7: Net factor income (\% of GDP), 1992-2007

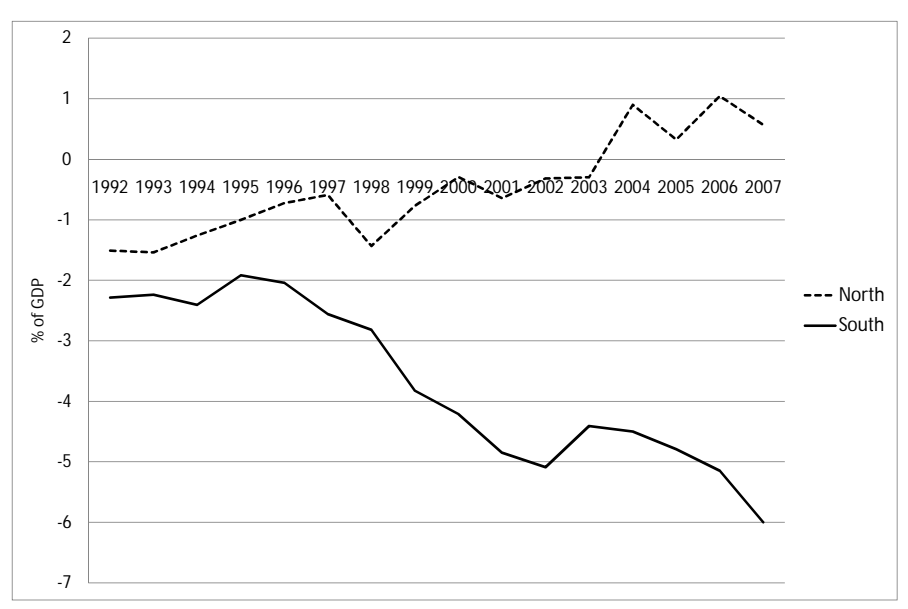

Figure 8: Trade balance (\% of GDP), 1992-2007

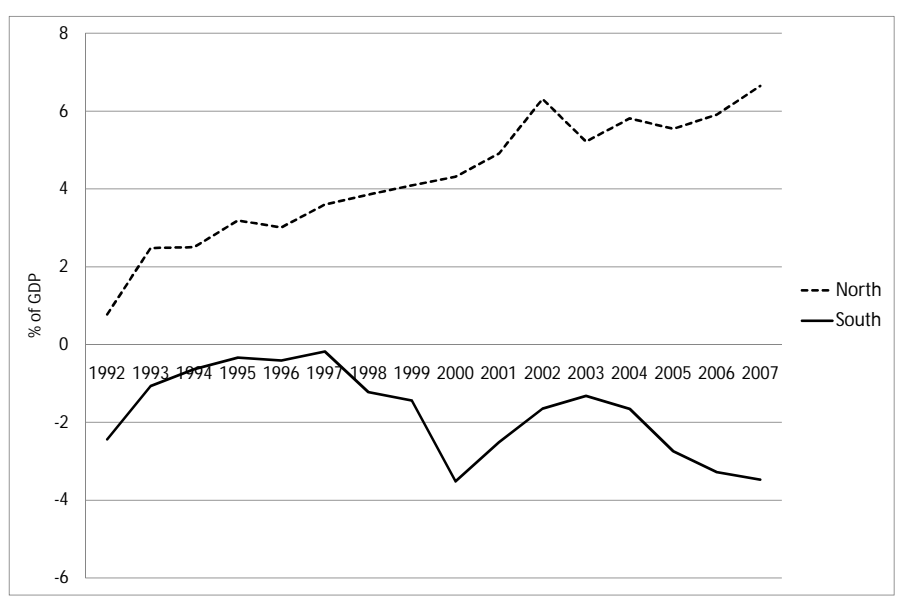

Source: AMECO database

below zero in 2007. Second, the magnitude of net current transfers is remarkable and allowed Southern countries to finance their trade balance deficits and net factor payments during the run-up to the EMU to a considerable extend by the receipt of net current transfers. During this time period the average sum of trade balance deficit and net factor payments amounted to 3.2 percent of GDP while the average net current transfers are 2.2 percent of GDP. Third, in the same way as net factor income payments, the decline in net current transfers is transmitted to the current account. We do not observe any compensatory adjustments in the trade balances of Southern countries. Considering the different components of the current account we can summarize that continuously growing current account surpluses of Northern countries are largely attributable to improving trade balances and net factor income receipts, whereas for Southern countries growing net factor income payments and declining net current transfers are primarily 
Figure 9: Net current transfers (\% of GDP), 1992-2007

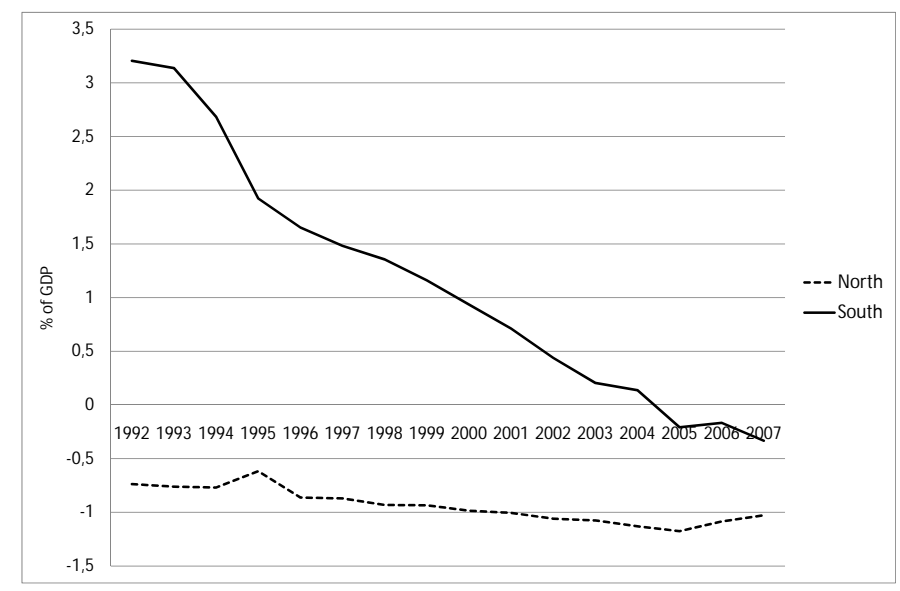

Source: AMECO database

responsible for the deterioration of their current account balances. We have also shown that diverging net foreign asset positions and induced net factor income payments further fuel internal and external imbalances in the Euro area.

In the next section we review the argument that the observed current account patterns are part of a catching-up process of countries in the South with their neighbors in the North.

\section{$3 \quad$ All a matter of economic convergence?}

Only very few papers recognize the evolution of external and internal imbalances across Euro area countries since the early 1990s. Those that do, generally seek to attribute the observed pattern of current account differentials to the European economic convergence process (Blanchard and Giavazzi (2002), Ahearne et al. (2007) and Arghyrou and Chortareas (2008)).

The theory of intertemporal maximization suggests that diverging current accounts are the natural consequence of a convergence process among countries with different levels of economic development. In particular in the presence of integrated real and financial markets, we should expect that countries with a lower per-capita income attract domestic and foreign investment as higher productivity and economic growth rates promise extra-ordinary rates of return. The productivity of the invested capital ensures that the accumulated foreign debt can be repaid ultimately. At the same time, these countries should consume more and consequently save less in anticipation of higher income growth in the future. Thus on both accounts, higher investment and lower saving rates, the theory of intertemporal maximization suggests that Southern countries should accumulate net foreign debt, while Northern countries should act as their net 
Figure 10: Relative real GDP per capita (average $=100), 1992-2007$

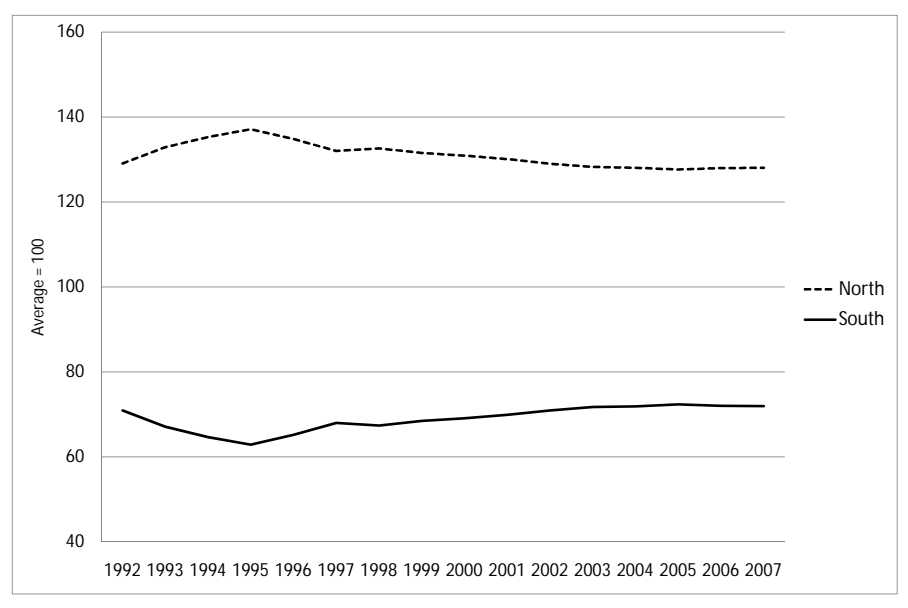

Source: AMECO database

foreign creditors.

In the same convergence process Southern countries will experience inflation-induced appreciation of their real exchange rate relative to Northern countries. Given a fixed nominal exchange rate, relatively higher inflation rates in Southern countries lead to an immediate real exchange rate appreciation and thus a less competitive international position. ${ }^{6}$ As a result, current account balances evolve in such a way as to match the capital account surpluses of countries in the South and deficits in the North.

In principle our findings in Figure 4 and 5, namely a moderate increase in private investment and a strong decline in private savings for Southern countries, are consistent with economic convergence. Also the literature seems to support this line of reasoning. However when looking further at the data we find that the economic convergence hypothesis does not stand up to the empirical facts as (1) real income differentials are persistent, (2) total factor productivity remains low in the South and (3) the terms of trade data do not point at a substantial loss in international competitiveness. We discuss each empirical fact in turn.

Figure 10 shows relative real GDP per capita for Northern and Southern countries over the time period 1992 to 2007. We find that in real terms Northern countries have about twice as much GDP per capita as Southern countries, and more surprisingly, that the European economic and monetary integration process has triggered little convergence among those two groups of countries. The gap is relatively persistent over the time spans of the run-up to EMU and

\footnotetext{
${ }^{6}$ Two complementary theories exist to explain the inflation-induced loss of international competitiveness during the convergence process. For a supply-side approach see Balassa (1964) and Samuelson (1964) and for a demandside approach see Baumol and Bowen (1966).
} 
Figure 11: Relative total factor productivity (average $=100$ ), 1992-2007

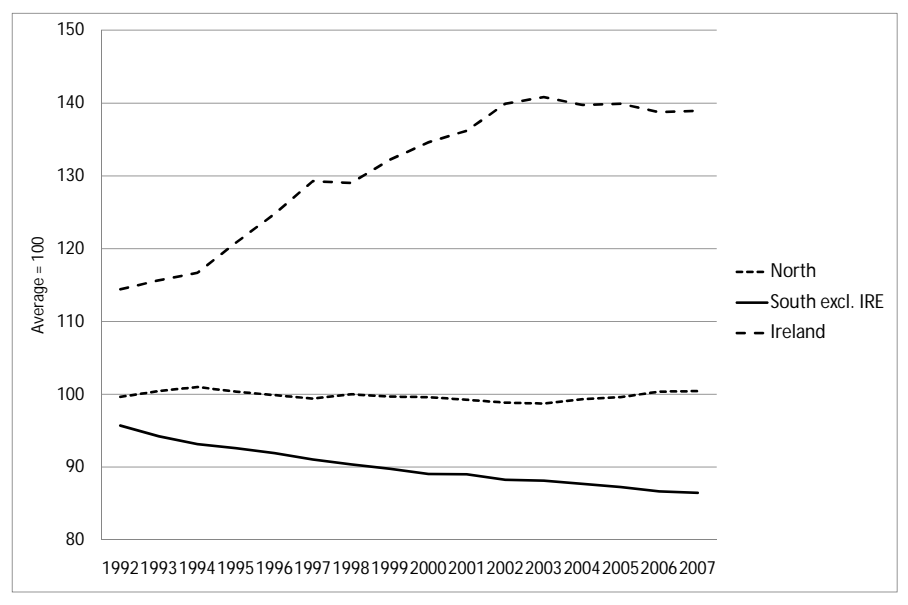

Source: AMECO database

the subsequent introduction of the Euro. The cause is shown in Figure 11 - diverging total factor productivity of both country groups over the years 1992 to $2007 .{ }^{7}$ Ireland constitutes an exception here with a strongly increasing total factor productivity, in particular during the run-up to EMU. Although the economic convergence hypothesis is framed within expectations of productivity and economic growth, the realization thereof, shown in Figures 10 and 11, is not in support. Given the persistent differences in relative income and productivity, we have either to assume that expectations of Southern countries are continuously off or they have other motives for consuming today.

Also the argument that inflation-induced appreciation of the real exchange rate and a concomitant loss of international competitiveness cause the current account deficits of the South can be contested.

At first sight the argument seems to find support in Figure 12 which presents producer price inflation rates for Northern and Southern countries over the time period 1992 to 2007. Inflation rates in Northern countries vary within the range of 1 to 3 percent over the total period, while Southern countries exhibit inflation rates that are at least 1 to 2 percent higher. This implies an annual appreciation of the real exchange rate by 1 to 2 percentage points, preceded by a considerably higher amount during the run-up to EMU. However we disagree with the use of inflation rates as a measure for external price competitiveness. Producer price inflation

\footnotetext{
${ }^{7}$ AMECO data show that while relative gaps of capital and employment rates between North and South (excl. Ireland) are gradually closing, diverging total factor productivity impedes an overall economic convergence process. Using OECD data on total factor productivity yields similar results. The corresponding figures are available from the authors upon request.
} 
Figure 12: Producer price inflation, 1992-2007

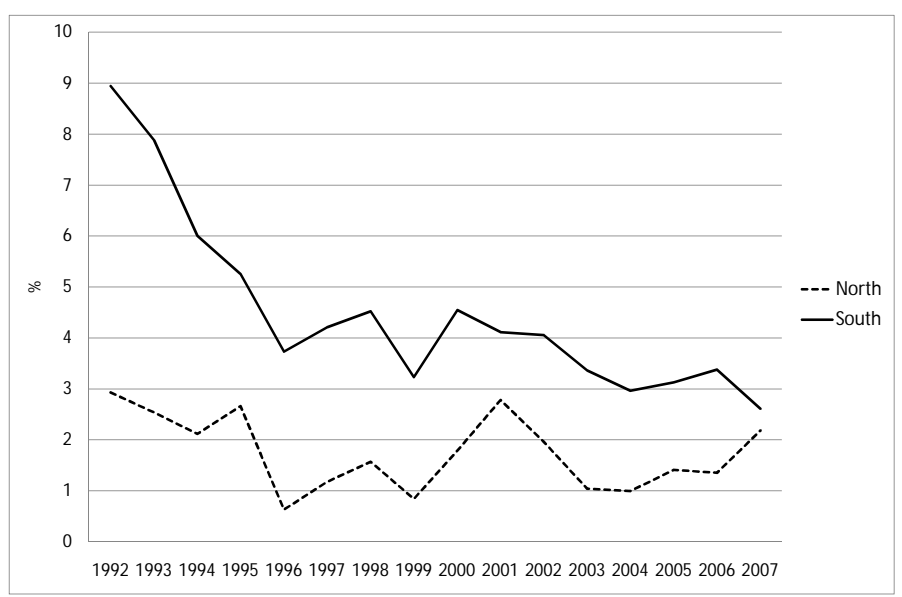

Source: AMECO database

Figure 13: Terms of trade $(1980=100), 1992-2007$

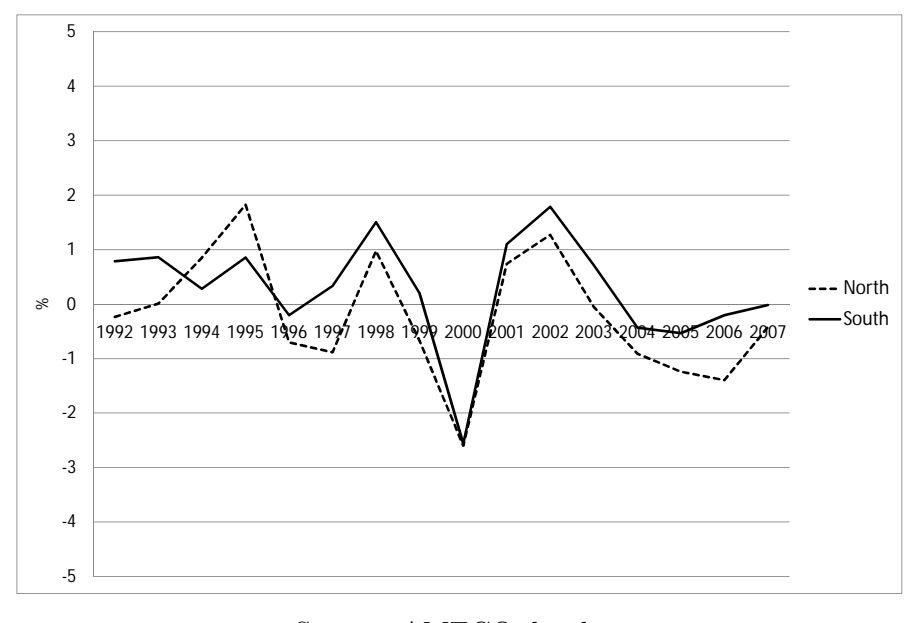

Source: AMECO database

rates combine price information on tradable and non-tradable goods, although both are subject to distinct sets of determinants, in particular for countries with different stages of economic development. A better measure to determine a country's external price competitiveness is its terms of trade, the ratio of export over import prices which exclude the non-tradable sector. Figure 13 shows the percentage change in the terms of trade for Northern and Southern countries over the time period 1992 to 2007 . We find that the relative loss of international competitiveness of Southern countries is far less pronounced than inflation differentials suggest. This shows that the observed correlation between real exchange rate movements and current account dispersion in the Euro area is at least partially spurious as the underlying mechanism of a relative loss 
in international competitiveness is not equally given. ${ }^{8}$ Moreover we have seen in the foregoing analysis that in particular for Southern countries net factor income and net current transfers play a much greater role in shaping the current account than the trade balance.

Taken together, it becomes obvious that arguments of economic convergence can be at best part of an explanation for growing internal and external imbalances.

Financial markets seem to have recognized that two important adjustment devices are missing to redress these imbalances, since North and South have common nominal interest rates and exchange rates. In our view other economic adjustment mechanisms are either ineffective or carry substantial risk. First, Southern countries could restore international price competitiveness and thus their external balances through a prolonged period of disinflation. Such a process goes along with a painful period of economic contraction and will only be effective over the medium to long run. Second, lower inflation in the South results in higher real interest rates which could encourage higher savings and less investment. The emergence of risk premiums in financial markets potentially works in the same way, but involves the substantial risk that debtor countries are pushed on the brink of insolvency. The situation of Greece is an alarming example. Third, wealth effects could act as important transmission channels. However our analysis has shown that - at least in the past - Southern countries did not adapt their consumption and savings behavior in the face of mounting external debt positions.

The apparent failure of these adjustment mechanisms and the associated risk justifies European economic policy coordination. We believe that the success of such policy coordination will largely hinge on a better understanding of country heterogeneity. Given that economic fundamentals cannot explain the persistent imbalances between North and South, we probably should pay more attention to behavioral aspects such as cross-country differences in spending habits, planning horizons and levels of risk aversion. Our analysis of both private savings behavior and government deficits suggests that in comparison to the North, Southern countries have a stronger preference for current consumption, which is consistent with a shorter planning horizon and higher willingness to take risks with external debts. Given the heterogeneous social, political and economic backgrounds from which Northern and Southern countries evolved, we believe that the current imbalances would continue to persist if in a counterfactual experiment both country groups were exposed to the same economic environment. As such we regard the descriptive analysis in this paper as a starting point for future empirical and theoretical research

\footnotetext{
${ }^{8} \mathrm{~A}$ possible transmission channel is that higher inflation in the South lowers the real interest rate and thereby induces consumption and investment.
} 
that emphasizes behavioral aspects.

\section{Concluding remarks}

In this paper we provide a systematic analysis of current internal and external imbalances in the Euro area that emerged with the introduction of the Euro as a common currency. This is an issue that has obtained scant attention in the past, but gained significance with the unfolding of Greek solvency problems. During the time period 1999 to 2007 we identify two groups of Euro area countries that were running an average current account surplus and deficit of 4.6 and 6.8 percent of GDP, respectively. The main drivers of the current account dispersion are the private sectors - households and firms - as the fiscal constraints of the Treaty of Maastricht have proved reasonably effective on the public sectors. For the private sectors we find that a tremendous decrease in savings of Southern countries from about 24 percent of GDP in the beginning of the 1990s to about 14 percent of GDP in 2007, reflected in a corresponding increase in consumption and to a lesser extend investment, is mainly responsible for the deterioration of their current accounts.

We argue that the sizable net foreign debt positions of about 80 percent of GDP constitute a considerable burden for Southern countries. In 2007 net factor income payments amounted to almost 6 percent of GDP. In general, net factor income payments and declining net current transfers systematically deteriorated the current account of Southern countries, since consumption and savings patterns did not adjust to the increased burdens. On the other hand, continuously improving trade balances and net factor income receipts are responsible for the growing current account surpluses of Northern countries.

In our view underlying fundamental economic factors are not capable to fully explain the observed imbalances in the Euro area. The common argument of economic convergence does not provide a satisfactory explanation of our observations. For that reason we think that fundamental economic differences need to be placed on par with behavioral considerations such as different spending habits, planning horizons and levels of risk aversion. In addition, a better understanding of the behavioral aspects in this context allows devising policy coordination and rules to contain these differences in behavior. The precise formulation of these rules is beyond the scope of this paper, but the lesson that we learn from the current situation is that a possible revision of the Stability and Growth Pact needs to place a greater weight on external imbalances.

Future research should address these issues. 


\section{Reference}

Ahearne, A., Schmitz, B. and von Hagen, J. (2007). Current Account Imbalances in the Euro Area, in A. Aslund and M. Dabrowksi (ed.), Challenges of Globalization - Imbalances and Growth, Peterson Institute for International Economics.

Arghyrou, M. and Chortareas, G. (2008). Current Account Imbalances and Real Exchange Rates in the Euro Area, Review of International Economics $\mathbf{1 6 .}$

Balassa, B. (1964). The purchasing-power parity doctrine: A reappraisal, Journal of Political Economy 72: 584-596.

Baumol, W. and Bowen, W. (1966). Performing Arts: The Economic Dilemma, Twentieth Century Fund.

Blanchard, O. and Giavazzi, F. (2002). Current Account Deficits in the Euro Area. The End of the Feldstein Horioka Puzzle?, Brookings Paper on Economic Activity 2.

Gros, D. (2010). Adjustment Difficulties in the GIPSY Club, CEPS Working Document No. 326.

Holinski, N., Kool, C. and Muysken, J. (2009). International Portfolio Balance - Modelling the External Adjustment Process, METEOR Research Memorandum 09/033.

Lane, P. and Milesi-Ferretti, G. (2005). A Global Perspective on External Positions, NBER Working Paper No. 11589.

Lane, P. and Milesi-Ferretti, G. (2007). The External Wealth of Nations Mark II: Revised and extended estimates of foreign assets and liabilities, 1970-2004, Journal of International Economics 73: 223-250.

Samuelson, P. (1964). Theoretical notes on trade problems, Review of Economics and Statistics 46: $145-154$. 